\title{
Reaction Response of Citrus Reticulate to Six Concentration of Jujube Water Extraction Infected With Meloidogyne Incognita under Greenhouse Conditions
}

\section{Sergany M. I', Helal E. M. Mona² , Tiurky, M. N. Shaimaa ${ }^{3}$, S. B. $\mathrm{Gad}^{4}$}

${ }^{1}$ Pesticides Dept. Fac. Of Agric., Mansoura Univ. Dk. Egypt.

${ }^{2}$ Citrus Division, Orchards Inst. Res. A.R.C., Mansoura, Egypt.

${ }^{3}$ Botany Dept., Fac of Science, Mansoura Univ

${ }^{4}$ Nematology Res. Unit, Agric. Zool. Dept, Fac. of Agric., Mansoura Univ. Mansoura, DK., Egypt.

\begin{abstract}
Greenhouse experiment was conducted to determined the effect of six concentrations of jujub leave water extract $(5,10,15,20,25$ and $30 \mathrm{ml} /$ plant) on Meloidogyne incognita infecting common mandarin comparing with oxamyl under greenhouse conditions. The obtained results indicated that all tested materials improved all the plant growth criteria and diminished nematode parameters as well. On the other hand, using jujube water extract at $30 \mathrm{ml} /$ plant gave the maximum values of shoot and root lengths; shoot and root fresh weights shoot dry matter, leaves number/plant, and branches, whereas the concentration of $5 \mathrm{ml} /$ plant showed the minimum values in this respect. Oxamyl ranked first in percentage reduction values of the number of juveniles in soil (90.1\%), galls $(86.5 \%)$, eggmasses (93.9\%) and eggs/egg mass number (63.33\%) on roots, respectively.
\end{abstract}

Key words: Control, Meloidogyne incognita, mandarin, jujube, water extract.

\section{Introduction}

Citrus trees are considered to be the most produced fruit trees in Egypt and all over the world. Several plant parasitic nematodes are recorded to attack citrus roots. Plant parasitic nematodes caused significant damage and losses, the root-knot nematodes (Meloidogyne spp.) are one of the most wide spread and damaging agricultural pests in the world causing an estimated US $\$ 100$ billion loss/ year worldwide (Oka et al ., 2000). They were widely distributed in the cultivated areas of Egypt causing remarkable crop losses. During the two last decades, nematode control was based mostly on the use of nematicides. However, because of environmental toxicity and cost of these chemicals, other control techniques are of a great goal. The improvement in plant growth and yield criteria after the addition of organic matter due to the disinfection of such plants with nematode and / or to the nutritive value of plant fresh or dry leaves and recorded by several investigators (Siddiqui and
Alam, 1988 a and b ; Almihanna et al., 1999). Jujube are known as anti-fungal, anti-bacterial, antiulcer, anti-inflammatory purposes and sedation, antispastic, antifertility/contraception, hypotensive and antinephritic, cardiotonic, antioxidant, immunostimulant, and wound healing properties(Jiang et al., 2007). Zizyphus jujube is a thorny Rhamnaceous plant that is widely distributed in Europe and Southeastern Asia. Fruits of this plant are edible and different parts of $\mathrm{Z}$. jujube possess multiple medicinal properties such as antifertility, analgesic, and anti-diabetes.

The present study was carried-out to evaluate the effect of six concentrations of jujube leave water extracts on growth of both common mandarin infected with $M$. incognita and $M$. incognita population comparing with oxamyl nematicide under greenhouse conditions. 


\section{Materials and Methods Source of Nematodes}

Second stage juveniles (J2) of Meloidogyne incognita (Kofoid \& White) Chitwood, were obtained from a pure culture of $M$. incognita that was initiated by a single eggmass propagated on coleus plants, Coleus blumei in the greenhouse of Nematology Research Unit,(NERU) Agricultural Zoology Department, Faculty of Agriculture, Mansoura University, Egypt, where this work was carried-out.

\section{Nematicide}

Oxamyl (Vydate) $24 \% \quad$ E.C, Methyl-N'N'dimethyl-N [(methyl) carbamyloxy]-1thioxamidate was used at the rate of $0.3 \mathrm{ml} / \mathrm{plant}$ as the recommended dose in this work.

\section{Preparation of Jujube water extract}

Followed the method of Harborne (1984) for the preparation of the water extract by taking 20 grams of dry sample of jujube leaves and added to distilled water until the final volume became $(200 \mathrm{ml})$ and left for half hour on horizontal shaker at medium speed and then the sample was left one hour and then the sample was filtrated by three layers of gauze cloth to remove hard plankton and then the obtained filtrates was used in the experiment.

\section{Time course experiment}

A greenhouse experiment was carried-out in order to evaluate the effect of six jujube water extract $(5,10$, $15,20,25,30 \mathrm{ml} /$ plant) on citrus plant infected with Meloidogyne incognita comparing with oxamyl at the recommended dose under greenhouse conditions (22 $\pm 3 \mathrm{C}^{\circ}$ ). Forty five citrus reticulate seedlings (one years old) growing in plastic bags $(15 \mathrm{~cm}-\mathrm{d})$ filled with $3 \mathrm{~kg}$ steam loamy sandy soil (1:1) (v:v) were chosen to conducted this experiment. Forty seedlings were separately inoculated with 2000 juveniles of $M$. incognita and left five seedlings (bags) without nematode to serve as check. The tested materials were separately added to five seedlings each one week after nematode inoculation, while five seedlings (bags) with nematode only were left without any treatment. Each treatment was replicated five times. Treatments were as follows:

1- Control (untreated plants and free from nematode).

2- Nematode infection alone $(\mathrm{N})$.

3 - $\mathrm{N}+$ oxamyl $(0.3 \mathrm{ml} / \mathrm{plant})$.

4- $\mathrm{N}+$ jujube extract ( $5 \mathrm{ml} /$ plant $)$.

$5-\mathrm{N}+$ jujube extract $(10 \mathrm{ml} /$ plant $)$.

$6-\mathrm{N}+$ jujube extract (15ml / plant).

$7-\mathrm{N}+$ jujube extract $(20 \mathrm{ml} /$ plant $)$

$8-\mathrm{N}+$ jujube extract $(25 \mathrm{ml} /$ plant $)$.

$9-\mathrm{N}+$ jujube extract $(30 \mathrm{ml} /$ plant $)$.
Plastic bags were then arranged in a randomized complete block design on a bench of greenhouse at $22 \pm 3^{\circ} \mathrm{C}$ and irrigated with tap water as needed. Plants were harvested after 45 days from nematode inoculation. Data dealing with plant length and weights of fresh shoot and root; and shoot dry matter of each plant / bag were measured and recorded. Infected roots were washed in tap water and examined for the numbers of galls and egg-masses and recorded. Number of juveniles (J2) per soil of each plant were counted and recorded. The root gall index (RGI) and eggmass index (EI) were estimated according to the scale given by Taylor and Sasser (1978) as follows: $0=$ no galls or egg-masses, $1=1-2$ galls or egg-masses, $2=3-10$ galls or egg-masses, $3=$ 11-30 galls or egg-masses, $4=31-100$ galls or eggmasses and $5=$ more than 100 galls or egg-masses. $M$. incognita (J2s) were separately extracted from $250 \mathrm{~g}$. soil of each treatment / replicate by sieving and modified Baermann technique (Goodey, 1957), counted, recorded and then determined for the soil of each plastic bag. Statistically, the obtained data were subjected to analysis of variance (ANOVA) (Gomez and Gomez, 1984) followed by Duncan's multiple ranges to compare means (Duncan, 1955).

\section{Results and Discussion}

Data presented in Table (1) verify the impact of six jujube leave water extract $(5,10,15,20,25,30$ $\mathrm{ml} /$ plant) on Citrus plants infected with Meloidogyne incognita under greenhouse conditions $\left(22 \pm 3^{\circ} \mathrm{C}\right)$. Obviously, the results indicated that all tested jujube leave water extract concentrations improved plant growth criteria and reduced nematode parameters. Among the tested concentrations, using jujube leave water extract at $30 \mathrm{ml} /$ plant showed the maximum values of shoot length $(21.5 \%)$, root length (57.9\%), shoot fresh weight $(85.0 \%)$, root fresh weight $(10.2 \%)$, shoot dry matter $(43.5 \%)$ number of leaves/plant (25.3\%), and number of branches $(51.4 \%)$, on the other side, jujube leave water extract at $5 \mathrm{ml} /$ plant showed the minimum percentage increase values of shoot length $(11.4 \%)$, root length $(41.8 \%)$, shoot dry matter $(29.0 \%)$, root fresh weight $(17.9 \%)$, shoot fresh weight $(48.6 \%)$, numbers of leaves/plant (20.8\%), branches ( $36.2 \%)$, respectively when compared with nematode alone. For the plants treated with other concentrations of jujube extract, represented the intermediate percentage increase values of such plant growth parameters respectively, comparing to nematode alone. Moreover, promising results was evident by using jujube water extract at $25 \mathrm{ml} /$ plant, followed by that of $20 \mathrm{ml} /$ plant. Oxamyl as a systematic nematicide gave the lowest percentage increase values of growth criteria among the tested concentrations, except in number of leaves (30.4\%) comparing to nematode alone. Moreover, control plants that free of nematode and receiving 
none of the tested materials gave considerable values of such tested citrus growth parameters which showed a high value of leaves number $(32.5 \%)$ over that of oxamyl $(27.9 \%)$, comparing to nematode alone (Table 1).

From the above results, root-knot nematodes cause giant cells to form in the roots, and this disrupts the root vascular system, reducing the uptake of water and nutrients and their transport from the roots to the shoots (Abad, 2003). The plant response to nematode parasitism thus causes morphological and physiological changes that affect photosynthetic processes (Hussey and Williamson, 1998).

The reduction in the length and weight of shoots, root weight increased in infected plants, possibly due to the formation of giant cells in root galling. Giant cells provide a nutrient sink on which the nematode feeds. As a result the plant is no longer able to provide nutrients to its upper part. This limitation of nutrient elements in the plant is probably the first effect that the nematode has on the physiology and metabolism of its host. These effects increase with the duration of infection (Melakeberhan et al., 1987). 
Reaction Response of Citrus Reticulate to Six Concentration of Jujube Water Extraction Infected With Meloidogyne Incognita under Greenhouse Conditions

\begin{tabular}{|c|c|c|c|c|c|c|c|}
\hline \multirow{2}{*}{ Preatments } & \multicolumn{2}{|c|}{ Plant length (cm) } & \multicolumn{2}{|c|}{ Plant fresh weight (g) } & \multirow{2}{*}{$\begin{array}{l}\text { Shoot dry } \\
\text { matter (g) }\end{array}$} & \multirow{2}{*}{$\begin{array}{r}\text { No. of } \\
\text { leaves }\end{array}$} & \multirow{2}{*}{$\begin{array}{c}\text { No. of } \\
\text { branches }\end{array}$} \\
\hline & Shoot & Root & Shoot & Root & & & \\
\hline Control & $\begin{array}{r}85.50 \mathrm{de} \\
(3.2)\end{array}$ & $\begin{array}{r}14.44 \mathrm{~d} \\
(8.1)\end{array}$ & $\begin{array}{r}95.76 \mathrm{c} \\
(17.8)\end{array}$ & $\begin{array}{r}13.27 \mathrm{~d} \\
(6.8)\end{array}$ & $\begin{array}{r}60.14 \mathrm{~d} \\
(9.2)\end{array}$ & $\begin{array}{r}10.25 \mathrm{~d} \\
(7.8)\end{array}$ & $\begin{array}{r}3.22 \mathrm{de} \\
(32.5)\end{array}$ \\
\hline $\begin{array}{l}\text { Nematode } \\
\text { infection alone } \\
(\mathrm{N})\end{array}$ & $82.81 \mathrm{e}$ & $\mathrm{N}$ alone & $82.81 \mathrm{e}$ & $\mathrm{N}$ alone & $82.81 \mathrm{e}$ & $\mathrm{N}$ alone & $82.81 \mathrm{e}$ \\
\hline $\begin{array}{c}+ \text { Oxamyl } \\
(0.3 \mathrm{ml} / \mathrm{plant})\end{array}$ & $\begin{array}{r}87.08 \text { cde } \\
(5.2)\end{array}$ & $\begin{array}{r}18.84 \mathrm{c} \\
(41.0)\end{array}$ & $\begin{array}{r}100.27 \mathrm{c} \\
(23.3)\end{array}$ & $\begin{array}{r}14.81 \mathrm{bc} \\
(0.0)\end{array}$ & $\begin{array}{r}66.87 \mathrm{c} \\
(21.4)\end{array}$ & $\begin{array}{r}12.39 \mathrm{bc} \\
(30.4)\end{array}$ & $\begin{array}{l}3.11 \mathrm{e} \\
(27.9)\end{array}$ \\
\hline $\begin{array}{r}\text { +Jujube } \\
\text { extract } \\
(5 \mathrm{ml} / \text { plant })\end{array}$ & $\begin{array}{r}92.24 \mathrm{bcd} \\
(11.4)\end{array}$ & $\begin{array}{r}18.95 \mathrm{c} \\
(41.8)\end{array}$ & $\begin{array}{r}120.85 \mathrm{~b} \\
(48.6)\end{array}$ & $\begin{array}{r}14.66 \mathrm{c} \\
(17.9)\end{array}$ & $\begin{array}{r}71.03 \mathrm{bc} \\
(28.9)\end{array}$ & $\begin{array}{r}11.48 \mathrm{c} \\
(20.8)\end{array}$ & $\begin{array}{r}3.31 \text { cde } \\
(36.2)\end{array}$ \\
\hline $\begin{array}{r}+ \text { Jujube } \\
\text { extract } \\
(10 \mathrm{ml} / \text { plant }) \\
\end{array}$ & $\begin{array}{r}93.12 \text { abcd } \\
(12.6)\end{array}$ & $\begin{array}{r}19.73 \\
\mathrm{abc} \\
(47.7)\end{array}$ & $\begin{array}{r}130.23 \mathrm{~b} \\
(60.2)\end{array}$ & $\begin{array}{r}15.27 \mathrm{abc} \\
(22.8)\end{array}$ & $\begin{array}{r}73.96 \mathrm{ab} \\
(34.3)\end{array}$ & $\begin{array}{r}12.53 \mathrm{~b} \\
(31.9)\end{array}$ & $\begin{array}{r}3.44 \text { abcd } \\
(41.6)\end{array}$ \\
\hline $\begin{array}{r}\text { Jujube } \\
\text { extract } \\
(15 \mathrm{ml} / \text { plant }) \\
\end{array}$ & $\begin{array}{r}95.82 \mathrm{ab} \\
(15.7)\end{array}$ & $\begin{array}{r}20.64 \\
a b \\
(54.5)\end{array}$ & $\begin{array}{r}144.83 \mathrm{a} \\
(78.1)\end{array}$ & $\begin{array}{r}15.97 \mathrm{ab} \\
(28.5)\end{array}$ & $\begin{array}{r}77.36 \mathrm{a} \\
(40.5)\end{array}$ & $\begin{array}{r}13.92 \mathrm{a} \\
(46.5)\end{array}$ & $\begin{array}{r}3.60 \mathrm{ab} \\
(48.1)\end{array}$ \\
\hline $\begin{array}{r}\mathrm{+Jujube} \\
\text { extract } \\
(20 \mathrm{ml} / \mathrm{plant}) \\
\end{array}$ & $\begin{array}{r}94.22 \mathrm{abc} \\
(13.8)\end{array}$ & $\begin{array}{r}19.35 \\
b c \\
(44.8) \\
\end{array}$ & $\begin{array}{r}141.31 \mathrm{a} \\
(73.8)\end{array}$ & $\begin{array}{r}14.94 \mathrm{bc} \\
(20.4)\end{array}$ & $\begin{array}{r}75.54 \mathrm{ab} \\
(37.1)\end{array}$ & $\begin{array}{r}11.50 \mathrm{c} \\
(21.1)\end{array}$ & $\begin{array}{r}3.37 \text { bcde } \\
(38.7)\end{array}$ \\
\hline $\begin{array}{r}\mathrm{H} \text { Jujube } \\
\text { extract } \\
(25 \mathrm{ml} / \text { plant })\end{array}$ & $\begin{array}{r}99.81 \mathrm{ab} \\
(20.5)\end{array}$ & $\begin{array}{r}20.21 \\
\mathrm{abc} \\
(51.3)\end{array}$ & $\begin{array}{r}146.76 \mathrm{a} \\
(80.5)\end{array}$ & $\begin{array}{r}15.64 \mathrm{abc} \\
(25.8)\end{array}$ & $\begin{array}{r}75.75 \mathrm{ab} \\
(37.5)\end{array}$ & $\begin{array}{r}11.60 \mathrm{bc} \\
(22.1)\end{array}$ & $\begin{array}{r}3.53 \mathrm{abc} \\
(45.3)\end{array}$ \\
\hline $\begin{array}{r}\text { +Jujube } \\
\text { extract } \\
\text { (30ml/plant) }\end{array}$ & $\begin{array}{r}100.58 \mathrm{a} \\
(21.5)\end{array}$ & $\begin{array}{r}21.09 \mathrm{a} \\
(57.9)\end{array}$ & $\begin{array}{r}150.39 \mathrm{a} \\
(84.9)\end{array}$ & $\begin{array}{r}16.32 \mathrm{a} \\
(31.3)\end{array}$ & $\begin{array}{r}79.06 \mathrm{a} \\
(43.5)\end{array}$ & $\begin{array}{r}11.90 \mathrm{bc} \\
(25.3)\end{array}$ & $\begin{array}{l}3.68 \mathrm{a} \\
(51.4)\end{array}$ \\
\hline L.S.D $0.05 \%$ & 7.94 & 1.61 & 10.79 & 1.29 & 6.08 & 1.00 & 0.28 \\
\hline
\end{tabular}

Table (1): The effect of six concentrations of jujube plant leave water extract and $0.3 \mathrm{ml} /$ plant oxamyl nematicide on physiological parameters of common mandarin after 45 days from nematode infection under greenhouse conditions $\left(22 \pm 3^{0} \mathrm{C}\right)$.

$\mathrm{N}=2000 \mathrm{~J}_{2}$ of $M$. incognita

Each value is the mean of five replicates

Means in each column followed by the same letter (s) did not differ at $\mathrm{P}<0.05$ according to Duncan multiple- range test

Number between parentheses represented the percentage of increase or decrease in plant growth response.

Data as depicted in Table (2) verify that using jujube plant water extract at six concentrations $(5,10,15$, 20,25 and $30 \mathrm{ml} /$ plant) in comparison with oxamyl at recommended dose $(0.3 \mathrm{ml} / \mathrm{plant})$ on common mandarin infected with $M$. incognita were significantly effective in diminishing numbers of juveniles recorded from soil, root gallings, females and eggmasses on root system as compared to those of the inoculated untreated check. It is interesting to observe that plant received jujube water extract at 30 $\mathrm{ml} /$ plant accomplished the highest percentage reduction of nematode parameters with the maximum values of $72.89 .50,84.5$ and $90.2 \%$ for females, number of nematode in soil, galls, eggmasses, of common mandarin comparing to nematode alone, respectively. However, plant receiving water extract of jujube plant at $5 \mathrm{ml} /$ plant gave the minimum values of the same nematode parameters that were amounted to $63.69,81.0$ and 80.9 .0 and $86.6 \% \%$ respectively as compared with nematode alone. Meanwhile, plant received $25 \mathrm{ml}$ of jujube water extract showed the intermediate values of the same nematode criteria with values of $70.77,83.0,82.6$ and $89.4 \%$, respectively comparing to nematode alone. Oxamyl as a systematic nematicide gave the least values of female's number $(62.46 \%)$, whereas it ranked first in percentage reduction values of juveniles numbers in $100 \mathrm{~g}$ soil $(90.1 \%)$, galls $(86.5 \%)$, and eggmasses $(93.9 \%)$ on roots, respectively as compared with nematode alone. 
Reaction Response of Citrus Reticulate to Six Concentration of Jujube Water Extraction Infected With Meloidogyne Incognita under Greenhouse Conditions

Table (2): The effect of six concentrations of jujube plant leave water extract and $0.3 \mathrm{ml} / \mathrm{plant}$ oxamyl nematicide on $M$. incognita parameters of common mandarin after 45 days from nematode infection under greenhouse conditions $(30 \pm 2 \circ \mathrm{C})$.

\begin{tabular}{|c|c|c|c|c|c|c|c|c|c|c|}
\hline Preatments & Females & $\operatorname{Red} \%$ & $100 \mathrm{~g} / \mathrm{soil}$ & Red\% & $\begin{array}{l}\text { No. of } \\
\text { galls } \\
\text { 1g/root }\end{array}$ & Red\% & RGI & $\begin{array}{l}\text { No. } \\
\text { eggmasses } \\
\text { 1g/root }\end{array}$ & $\begin{array}{l}\text { Red } \\
\%\end{array}$ & $E . I^{* * *}$ \\
\hline $\begin{array}{l}\text { Nematode } \\
\text { infection alone } \\
(\mathrm{N})\end{array}$ & $325 \mathrm{a}$ & $\overline{----}$ & $1000 \mathrm{a}$ & $-\overline{---}$ & $517 \mathrm{a}$ & $-\overline{---}$ & $\overline{----}$ & $246 \mathrm{a}$ & $\begin{array}{l}---- \\
\end{array}$ & $-\overline{---}$ \\
\hline $\begin{array}{llr}\mathrm{N} & + & \text { Oxamyl } \\
& (0.3 \mathrm{ml} / \text { plant })\end{array}$ & $122 \mathrm{~b}$ & 62.46 & $99 \mathrm{c}$ & 90.10 & $70 \mathrm{~d}$ & 86.5 & 4 & $15 \mathrm{e}$ & 93.9 & 4 \\
\hline $\begin{array}{c}\mathrm{N}+\text { Jujube extract } \\
(5 \mathrm{ml} / \mathrm{plant})\end{array}$ & $118 \mathrm{bc}$ & 63.69 & $190 \mathrm{~b}$ & 81.00 & $99 \mathrm{~b}$ & 80.9 & 4 & $33 \mathrm{~b}$ & 86.6 & 4 \\
\hline $\begin{array}{r}\mathrm{N}+\mathrm{Jujube} \text { extract } \\
(10 \mathrm{ml} / \mathrm{plant})\end{array}$ & $106 \mathrm{~cd}$ & 67.38 & $175 \mathrm{~b}$ & 82.50 & $95 \mathrm{bc}$ & 81.6 & 4 & 29 bcd & 88.2 & 4 \\
\hline $\begin{array}{c}\mathrm{N}+\mathrm{Jujube} \text { extract } \\
(15 \mathrm{ml} / \mathrm{plant})\end{array}$ & $93 \mathrm{de}$ & 71.38 & $160 \mathrm{~b}$ & 84.00 & $85 \mathrm{bcd}$ & 83.6 & 4 & $25 \mathrm{~cd}$ & 89.8 & 4 \\
\hline $\begin{array}{c}\mathrm{N}+\text { Jujube extract } \\
\text { (20ml/plant) }\end{array}$ & $110 \mathrm{bc}$ & 66.15 & $185 \mathrm{~b}$ & 81.50 & $98 \mathrm{~b}$ & 81.0 & 4 & $32 \mathrm{bc}$ & 86.9 & 4 \\
\hline $\begin{array}{c}\mathrm{N}+\text { Jujube extract } \\
(25 \mathrm{ml} / \mathrm{plant})\end{array}$ & $95 \mathrm{de}$ & 70.77 & $170 \mathrm{~b}$ & 83.00 & $90 \mathrm{bc}$ & 82.6 & 4 & $26 \mathrm{bcd}$ & 89.4 & 4 \\
\hline $\begin{array}{c}\mathrm{N}+\text { Jujube extract } \\
\text { (30ml/plant) }\end{array}$ & $88 \mathrm{e}$ & 72.92 & $105 \mathrm{c}$ & 89.50 & $80 \mathrm{~cd}$ & 84.5 & 4 & $24 \mathrm{~d}$ & 90.2 & 4 \\
\hline L.S.D. 0.05 & 13.09 & ----- & 33.18 & ---- & 17.37 & ---- & ---- & 7.83 & ---- & ---- \\
\hline
\end{tabular}

$\mathrm{N}=2000 \mathrm{~J}_{2}$ of $M$. incognita.

Each value is the mean of five replicates.

** Root gall index (RGI) or egg-masses index (EI) was determined according to the scale given by Taylor\& Sasser (1978) as follows : $0=$ no galls or eggmasses, $1=1-2$ galls or eggmasses , $2=3-10$ galls or eggmasses, 3=11-30 galls or eggmasses, $4=31-100$ galls or eggmasses and 5= more than 100 galls or eggmasses.

As for the using of six concentrations of jujube water extract on common mandarin infected with $M$. incognita in comparison with oxamyl under greenhouse conditions, all tested concentrations significantly recorded the increments of plant growth characters and suppressing nematode parameters as well. The concentration of $30 \mathrm{ml} /$ plant represented the maximum values of improving plant growth parameters and that of suppressing nematode criteria. Moreover, because of $M$. incognita endo-parasitic and sedentary nature in root, all tested concentrations are effective in suppressing it to great extent in this investigation. This is not surprising since jujube plant leaves contains 3-O-a-L-rhamnopyranosyl (1-2)aarabinopyranosyl-20-O-(2,3)-di-O-acetyla-L-

rhamnopyranosyl ujubogenin. Saponin from leaves and stem are 3-O- ((2-O- alpha - D - furopyranosyl 3- O- beta - D -glucopyranosyl) - alpha - L arabinopyranosyl) jujubogenin and (6"'sinapoylspinosin, 6"'- feruloylspinosin and 6"'-pcoumaroylspinosin (Mahajan and Chopda 2009).

It is concluded that, jujube plant leave water extracts may be used as a substitutional way to partially nullifying the adverse effect of Meloidogyne incognita on growth of citrus reticulate seedlings (one years old) after 45 days from infection.

\section{References}

1. Abad, P., Favery, B., Rosso, M. Castagnone-Sereno, P. (2003). Root-knot nematode parasitism and host response: molecular basis of a sophisticated interaction. Mol. Plant Path., 4: 217-224.

2. Almihanna, A. A., Belal, M. M. and Farahat, A. A. (1999). The addition of chicken manure and eucalyptus dry leaves in relation to the management of Heterodera avenae and the incidence soil-borne fungi. J. Agric. Sci., Mans. Univ., 24(8): 4221-4228

3. Duncan, D. B. (1955). Multiple range and multiple, F-test Biometrics, 11: 1-42.

4. Gomez, K. A. and Gomez, A. A. (1984). Statistical procedures for Agricultural Research. 2nd Ed., John Wiley and Sons: Inc., New York.

5. Goodey, J. B. (1957). Laboratory methods for work with plant and soil nematodes. Tech. Bull. No. 2. Min. Agric. Fish Ed. London, $47 \mathrm{pp}$

6. Harborne, I.B. (1984).Phytochemical methods . Auid to modern technology of plant analysis.2nd ed. Chpma Hall,London,Newyork:282.

7. Hussey R. S. and Williamson,V. M. (1998). Physiological and molecular aspects of nematode parasitism. In: Plant and Nematode Interactions

8. Jiang J. G., Huang, X. J., Chen, J. and Lin, Q. S. (2007). Comparison of the sedative and hypnotic effects of flavonoids, saponins, and polysaccharides extracted from Semen Ziziphus jujube. Nat. Prod. Res., 21 (4): 310-320. 
9. Mahajan R. T., Chopda M. Z. (2009). Phyto-Pharmacology of Ziziphus jujuba Mill- A plant review. Phcog. Rev., 3: 3209

10. Melakeberhan H., Webster, J. M., Brooke, R. C., D’Auria, J. M. and Cackette, M. (1987). Effect of Meloidogyne incognita on plant nutrient concentration and its influence on the physiology of beans. J. Nema., 19: 324-330.

11. Oka, Y., Necar, S., Putievesky, E., Ravid, V., Yaniv, Z. an Spiegel, Y. (2000). Nematicidal activity of essential oils and their components against the root-knot nematode. J. Phyto. 90 (7): 710-715.
12. Siddiqi, M. A. and Alam, M. M. (1988b). Control of rootknot and reniform nematodes by bare root dip in leaf extracts of margosa and Persian lilac. Z. Pflanzzenk Dflanzenschut, 95: 138-142.

13. Siddiqui, M. A. and Alam, M. M. (1988a). Control of plant parasitic nematodes by soil amendment with marigold plant wastes. Pak. J. Nematol., 6(2): 55-63.

14. Taylor, A. L., and Sasser, J. N. (1978). Biology, identification and control of root-knot nematodes (Meloidogyne species). Raleigh, NC: North Carolina State University Graphics. 